Научная статья

УДК 316.61

DOI: 10.18101/2307-3330-2021-1-40-44

\title{
МЕЖЛИЧНОСТНЫЕ ОТНОШЕНИЯ МЛАДШИХ ПОДРОСТКОВ СО СВЕРСТНИКАМИ В РЕАЛЬНОМ И ВИРТУАЛЬНОМ ПРОСТРАНСТВЕ
}

\author{
(C) Гармаева Татьяна Владимировна \\ кандидат психологических наук, \\ Бурятский государственный университет имени Доржи Банзарова \\ 670000, Россия, г. Улан-Удэ, ул. Смолина, 24a \\ gtv_2004@rambler.ru

\section{(C) Дунаева Александра Евгеньевна} \\ бакалавр, \\ Бурятский государственный университет имени Доржи Банзарова \\ Россия, 670000, г. Улан-Удэ, ул. Смолина, 24a \\ dae.dunaeva@yandex.ru
}

\begin{abstract}
Аннотация. В представленной статье содержится анализ исследований вопросов развития межличностных отношений младших подростков со сверстниками, а также современное состояние интернет-коммуникации в подростковой среде. Также обобщены результаты эмпирического исследования специфики межличностных отношений современных учеников в условиях дистанционного обучения и работы по оптимизации их взаимодействия, развития сплоченности в классе и снижения конфликтности посредством информационно-коммуникационных технологий.

Ключевые слова: межличностные отношения, младшие подростки, информационно-коммуникационные технологии, конфликтность в классе, удовлетворенность классом, психологический климат в классе, оптимизация межличностных отношений, онлайн-коммуникация подростков.
\end{abstract}

\section{Для цитирования}

Гармаева Т. В., Дунаева А. Е. Межличностные отношения младших подростков со сверстниками в реальном и виртуальном пространстве // Вестник Бурятского государственного университета. Образование. Личность. Общество. 2021. Вып. 1. С. 40-44.

Информационно-коммуникативные технологии, проникающие во все сферы деятельности человека, являются особо привлекательными для современных подростков и способствуют формированию умения работать с информацией (находить, анализировать, интегрировать, оценивать и создавать информацию в разных формах и различными способами, кратко и ясно излагать свои мысли при общении), развитию коммуникативности, умению сотрудничать, искать пути решения поставленной задачи [2]. В развитии современного общества отмечается растущая информатизация, которая ведет к резкому повышению воздействия культурных кодов, интерпретационных схем и парадигм на чувства и настроения подрастающего поколения. При этом активно и целенаправленно применяются методы манипулирования массовым и индивидуальным сознанием детей и под- 
T. В. Гармаева, А. Е. Дунаева. Межличностные отношения младших подростков со сверстниками в реальном и виртуальном пространстве

ростков, включения их в те или иные информационно-коммуникационные среды информационного общества (выключения из них). Юный человек нового тысячелетия - это человек с новым менталитетом, новым сознанием, стремящийся к единению с другими. То отражается на характере межличностного общения и поведения.

Как известно, межличностное общение - это обязательное условие совместной жизни людей. Без него нельзя представить полноценного формирования психических процессов развивающейся личности в равной мере, как и невозможна полноценная социализация в обществе. На протяжении многих лет проблема межличностных отношений остается все еще актуальной. Исследованием специфики межличностных отношений занимались такие выдающиеся ученые, как В. Н. Мясищев, Е. П. Ильин, А. В. Петровский. Наиболее сензитивным периодом для развития навыков межличностного общения и основных форм межличностного поведения является подростковый возраст, когда начинают активно закладываться нравственные и моральные основы, формируется отношение к себе, окружающим и обществу в целом, формируются основные черты личности. При этом подростки дифференцируют физическую и психологическую близость при общении [1]. Первая важна им со стороны родителей и педагогов, а в отношении психологической близости в приоритете оказываются друзья и сверстники, с которыми они общаются и в виртуальном пространстве интернета [1;3].

В исследованиях Г. У. Солдатовой указано на дифференциацию виртуальных друзей и знакомых - собственно «френдов» и подписчиков. Первые допускаются к просмотру размещаемой подростком информации, фотографий, репостов, с ними ведутся переписки, они могут включаться в виртуальные полилоги. Тогда как для вторых открыты лишь избранные публикации. Зарубежные и российские школьники различаются по своему отношению к подписчикам: у зарубежных школьников часть их виртуальных «френдов» им незнакома, более того, они не могут назвать четкой причины добавления их в число таковых; в свою очередь, российские школьники в большинстве своем добавляют в друзья только четко идентифицируемых ими людей [3].

Сравнение подростков, пользующихся и не пользующихся интернетом, разрушает миф о его вреде для реального общения. Интернет-дети значительно больше общаются со сверстниками, с родителями, посещают кружки и секции, ходят на свидания. Это новый способ жизни при содействии информационных технологий, основа которого - реальное и виртуальное общение как единая система. В интернете появился аналог межличностного общения в форме социальных сетей. Юные респонденты в массовом опросе и интервью поставили реальное общение на первое место и вывели формулу: отношения начинаются в интернете и продолжаются в жизни, и наоборот.

Межличностные отношения в младшем подростковом возрасте развиваются в нескольких направлениях: в школе между учителем и ребенком; в семье между ребенком и родителями; в школьном коллективе между детьми. Отношения с другими людьми важны для ребенка в любом возрасте, однако нередко в классных коллективах случаются конфликтные ситуации, которые негативно сказы- 
ваются на психологическом климате и являются причиной снижения социометрического статуса младшего подростка. Это обусловливает необходимость оказания своевременной психологической помощи подросткам, в связи с чем нами было проведено исследование особенностей развития межличностных отношений младших подростков и психолого-педагогических условий их успешной оптимизации средствами информационно-коммуникационных технологий. Выборку составили 41 учащийся 6-х классов одной из средних общеобразовательных школ Республики Бурятия.

Анализ результатов позволил определить уровень конфликтности, удовлетворенности каждого ученика классом и социально-психологический климат взаимодействия, выявить уровень сплоченности ученического коллектива. Работа была проведена посредством таких методик, как «Мой класс» (Ю. 3. Гильбух), «Социометрия» (Дж. Морено), и разработанной А. Н. Лутошкиным карты-схемы изучения психологического климата в классе.

Полученные результаты свидетельствуют о среднем уровне конфликтности в классе и удовлетворенности школьным коллективом наряду с низкими показателями сплоченности. Относительно социометрических статусов учеников выявлено, что больше всего в разных классах учащиеся попали в категории «принятые» или «непринятые». Так, в экспериментальном классе процент «изолированных» выше, чем в контрольной группе, 13 и 6\% соответственно. В число «популярных» в экспериментальном классе вошли 12\% учеников, в контрольной группе - 16\%. Это подростки, получившие наибольшее количество положительных выборов, очень общительные и популярные среди своих одноклассников, умеющие устанавливать контакт. Группу «предпочитаемые» в экспериментальном классе составили 29\%, а в контрольной - 18\%. У данных подростков не отмечены конфликтные ситуации с одноклассниками, чаще всего они стараются прилежно учиться. Сверстники охотно общаются с ними, а также организовывают совместные творческие дела. Статус «принятые» в экспериментальной группе имеют 46\% учащихся, тогда как в контрольном - 35\%. Это те, кто избегает конфликтов с одноклассниками и стараются устанавливать с ними контакт. В контрольном классе также были обнаружены ученики, к которым сверстники обращаются в крайнем случае, это «непринятые» $(35 \%)$.

Изучение характера взаимоотношений младших подростков в обоих классах показал слабую сплоченность и отсутствие единства коллектива. Ребята чаще не имеют желания проводить время вместе вне уроков. Большинство детей считают, что их коллектив пассивен и инертен. По степени эмоционального благополучия и удовлетворенности членами группы различными сторонами жизни класса, составляющих психологический климат в целом, в обоих классах выявлены преимущественно низкие показатели данных критериев. Так, в разных классах 67 и $65 \%$ ребят их коллектив устраивает не полностью и социально-психологический климат они оценивают как неблагоприятный. В коллективе бывают случаи межличностных конфликтов, атмосфера нередко враждебна. Для данного коллектива характерны взаимные выпады и непонимание внутри него. 
T. В. Гармаева, А. Е. Дунаева. Межличностные отношения младших подростков со сверстниками в реальном и виртуальном пространстве

При ранжировании возможных причин, способствующих сплоченности коллектива, значимы «чувство гордости за свой класс», «уважение членов коллектива к мнению других», «эмоциональное единение в трудных ситуациях». Среди обусловливающих разобщенность в классе были отмечены отсутствие совместной деятельности и желания проводить время вместе, инертность и пассивность ученического коллектива, а также некорректные и иногда резкие критические замечания ребят относительно друг друга.

В целом результаты диагностики свидетельствуют о необходимости осуществления определенной работы по сплочению коллектива младших подростков, снижению уровня конфликтности и дискомфорта межличностного общения между ними, а также становлению благоприятного психологического климата в классе. Разрабатывая программу оптимизации межличностных отношений младших подростков со сверстниками, было учтено, что определенное время подростки проводят в социальных сетях, в своих гаджетах. Это обусловило выбор информационно-коммуникационных технологий в помощь реализации запланированных занятий в работе педагога-психолога и классных руководителей.

Программа была проведена с использованием различных интернет-платформ (в частности, «Zoom»), мессенджеров и видеосвязи, позволяющих быстро информировать и организовывать учащихся («Viber», «Вконтакте», «Wats up»). Преимущество групповой работы состоит в том, что общение в коллективе противодействует отчуждению и чувству одиночества, способствует получению обратной положительной связи от участников группы. На занятиях мы использовали проектную деятельность, просмотр мультипликационных материалов, а также онлайн-игры с целью активизации познавательного интереса, формирования активной жизненной позиции, толерантности, эмпатии и взаимоуважения. Также программа была нацелена на формирование у младших подростков понятия «единый, дружный коллектив», общего командного духа путем сплочения класса и развития ответственности и вклада каждого участника в решение общих задач. С позиции коммуникативного развития проведенные мероприятия были направлены на формирование у них основ коммуникативной культуры и снижение конфликтности в классе.

В силу вынужденного дистанционного обучения в образовательных организациях повторная диагностика характера межличностных отношений учеников посредством тех же методик была проведена в онлайн-режиме, то есть также с использованием информационно-коммуникативных технологий, к которым подростки уже привыкли. В частности, были разработаны google-формы для проведения опроса учащихся. Сравнительный анализ возможной динамики межличностных отношений подростков при завершении программы формирующей работы был осуществлен посредством метода математической статистики t-критерия Стьюдента, показавшего значительные изменения в экспериментальной группе по выбранным критериям диагностики. В контрольном классе изменение показателей находится в «зоне незначимости».

Полученные результаты и проведенная работа с младшими подростками показали, во-первых, эффективность реализованной программы оптимизации меж- 
личностных отношений в ученическом классе, во-вторых, возможность и необходимость использования информационно-коммуникативных технологий как при ее реализации, так и в таком направлении профессиональной деятельности педагогов-психологов, как диагностика.

Статья поступила в редакиию 25.02.2021; одобрена после рецензирования 15.03.2021; принята к публикации 09.04.2021.

\section{Литература}

1. Барканова О. В. Активное социально-психологическое обучение. Красноярск: Изд-во Красноярского гос. пед. ун-та им. В. П. Астафьева, 2015. 235 с. Текст: непосредственный.

2. Доржиева Л. Б., Намсараева С. Д. Информационно-коммуникативные технологии как ресурс формирования ценностных ориентаций современных детей и подростков // Наука и школа. 2016. № 3. С. 106-110. Текст: непосредственный.

3. Солдатова Г. У., Теславская О. И. Особенности межличностных отношений российских подростков в социальных сетях // Национальный психологический журнал. 2018. № 3. С. 12-22. Текст: непосредственный.

\section{INTERPERSONAL RELATIONSHIPS OF YOUNGER ADOLESCENTS WITH THEIR PEERS IN REAL AND VIRTUAL SPACE}

Tatyana V. Garmaeva

Cand. Sci. (Psychology)

Dorzhi Banzarov Buryat State University

24a Smolina St., Ulan-Ude 670000, Russia

gtv_2004@rambler.ru

Aleksandra E. Dunaeva

Bachelor,

Dorzhi Banzarov Buryat State University

24a Smolina St., Ulan-Ude 670000, Russia

dae.dunaeva@yandex.ru

Abstract. The article presents an analysis of research on the development of interpersonal relationships of younger adolescents with their peers, and considers the current state of Internet communication in adolescent environment. It also summarizes the results of an empirical study of the specifics of interpersonal relationships of modern students in the conditions of distance learning, and work on optimizing their interaction, developing cohesion in the classroom and reducing conflict through information and communication technologies.

Keywords: interpersonal relations; younger adolescents; information and communication technologies, conflict in the class; satisfaction with class; psychological climate in the class; optimization of interpersonal relationships; online communication of adolescents.

\section{For citation}

Garmaeva T. V., Dunaeva A. E. Interpersonal Relationships of Younger Adolescents with their Peers in Real and Virtual Space. Education. Person. Society. 2021; 1: 40-44 (In Russ.).

The article was submitted 25.02.2021; approved after reviewing 15.03.2021; accepted for publication 09.04.2021. 